\title{
KONSUMSI SERAT, KALIUM DAN HUBUNGANNYA DENGAN KADAR LOW DENSITY LIPOPROTEIN (LDL) PASIEN PENYAKIT JANTUNG KORONER
}

\author{
Emy Yuliantini, Cahyati, Afriyana Siregar
Politeknik Kesehatan Kementerian Kesehatan Bengkulu, Jurusan Gizi, Jalan Indragiri Nomor 03 Padang Harapan Kota Bengkulu Emyardi08@yahoo.com

\begin{abstract}
Changing patterns of human life cause various diseases, such as infectious diseases and malnutrition to degenerative diseases, including heart disease (cardiovascular). One of the major risk factors of cardiovascular diseases characterized by elevated levels of total cholesterol and LDL cholesterol. Fruits and vegetables are also an important part of the diet to prevent cardiovascular disease, by providing vitamins, minerals, fiber and potassium. This research was conducted in Poly of Cardio Hospital Outpatient Dr.M.Yunus design used was observational analytic with cross-sectional approach. Sampling by means of purposive sampling with a sample numbering 81 people. Data consumption of fiber and potassium patients obtained by filling out a form semiquantitative FFQ is eaten last month. The results showed that there is a relationship between fiber intake $(\mathrm{p}$-value $=0.001)$, the consumption of potassium $(\mathrm{p}$-value $=0.000)$ with LDL cholesterol levels in outpatients at Poly of Cardio Dr. M. Yunus Bengkulu. Nutritionist in collaboration with Doctors and Nurses in Heart Poli Dr. M Yunus Bengkulu in the form of consultation and counseling when CHD patients examination every month.
\end{abstract}

Keywords: Consumption of fiber, potassium consumption, LDL Cholesterol Levels

\begin{abstract}
Abstrak: : Perubahan pola hidup manusia menyebabkan berbagai penyakit, seperti penyakit infeksi dan rawan gizi ke penyakit degeneratif, diantaranya adalah penyakit jantung (kardiovaskuler). Salah satu faktor resiko utama penyakit kardiovaskuler ditandai dengan adanya peningkatan kadar kolesterol total dan kolesterol LDL. Buah dan sayuran juga merupakan bagian penting dari diet untuk mencegah penyakit kardiovaskuler, dengan memberikan vitamin, mineral, serat dan kalium. Penelitian ini dilakukan di ruangan Poli Jantung Rawat Jalan RSUD Dr.M Yunus desain yang digunakan adalah observasional analitik dengan pendekatan cross-sectional. Pengambilan sampel dengan cara Purposive Sampling dengan sampel berjumlah 81 orang. Data konsumsi serat dan kalium pasien diperoleh dengan cara mengisi formulir FFQ semi kuantitatif yang dimakan sebulan terakhir. Hasil penelitian menunjukkan bahwa ada hubungan konsumsi serat ( $\mathrm{p}$ value $=0,001$ ), konsumsi kalium ( $\mathrm{p}$-value $=0,000$ ) dengan kadar kolesterol LDL pada pasien rawat jalan di Poli Jantung Dr. M. Yunus Bengkulu. Ahli Gizi bekerja sama dengan Dokter dan Perawat di Poli Jantung Dr. M Yunus Bengkulu dalam bentuk konsultasi dan penyuluhan saat pasien PJK melakukan pemeriksaan setiap bulannya.
\end{abstract}

Kata Kunci : Konsumsi Serat, Kalium, Kadar LDL, Pasien Penyakit Jantung

Kemajuan perekonomian sebagai dampak dari pembangunan negara-negara sedang berkembang, Sebagaimana di Indonesia menyebabkan perbaikan pada tingkat hidup masyarakat. Hal ini menjadikan derajat kesehatan masyarakat meningkat, di samping itu terjadi pula perubahan pola hidup. Perubahan pola hidup ini yang menyebabkan pola penyakit, seperti penyakit infeksi dan rawan gizi ke penyakit-penyakit degeneratif, diantaranya adalah penyakit jantung (pembuluh darah (kardiovaskuler). (Supriono, 2008).

Penyakit Jantung Koroner (PJK) merupakan keadaan yang terjadi penimbunan plak pembuluh darah koroner. Hal ini menyebabkan arteri koroner menyempit atau tersumbat. Arteri koroner merupakan arteri 
yang menyuplai darah ke otot jantung dengan membawa oksigen yang banyak. Terdapat beberapa faktor memicu penyakit ini yaitu gaya hidup, faktor genetik, usia dan penyakit penyerta yang lain. (Norhasimah, 2010).

Konsumsi makanan khususnya dari asupan energi dan asupan lemak total berhubungan dengan status gizi. Asupan makanan yang tinggi lemak merupakan faktor utama meningkatkan kadar LDL (Kolesterol Jahat) dan menurunkan kadar HDL (Kolesterol baik) (Soeharto, 2004).

Buah dan sayuran merupakan bagian penting dari diet untuk penyakit kardiovaskuler sebagai sumber vitamin, mineral, antioksidan dan serat. The North Dakota State University Service melaporkan bahwa makan 5-9 porsi sehari buah dan sayuran menyediakan energi dan mengurangi penyakit. Hasil penelitian Esmaillzadeh, (2007) menyimpulkan bahwa masyarakat yang mengkunsumsi diet sehat seperti sayuran, kacang kacangan, dan buah-buahan memiliki resiko rendah terhadap penyakit jantung dan sindroma metabolik. Asupan kalium harian sebesar $1.600 \mathrm{mg}$ mampu menurunkan risiko stroke lebih dari $20 \%$ (Ervira, 2013).

Salah satu upaya untuk mengontrol fungsi jantung yaitu dengan cara mengkonsumsi banyak serat mencegah adanya penyerapan kembali asam empedu kolesterol dan lemak, sehingga serat dikatakan mempunyai efek hipolipediamik (Muchtadi, 2005). Serat dapat menurunkan kadar kolesterol dengan jalan mengikat asam empedu dan dikeluarkan bersama feses, akibatnya lemak tidak dapat diserap karena tidak ada pengemulsinya dan akhirnya dapat menghambat risiko munculnya penyakit jantung koroner (Sugiani, 2004).

Penelitian Hutter, 2004 yang melibatkan 4466 orang yang berasal dari National Heart, Lung, and Blood Institute Family Heart Study menunjukkan bahwa konsumsi buah dan sayur berbanding terbalik dengan nilai LDL-kolesterol dalam tubuh yang merupakan faktor resiko untuk penyakit kardiovaskular. Dengan mengkonsumsi buah dan sayur dalam jumlah tertentu dapat mengurangi konsentrasi LDL-kolesterol dalam tubuh (Luc et al, 2004).

Rumah Sakit Umum Daerah (RSUD) Dr. M Yunus merupakan satu-satunya rumah sakit rujukan di Provinsi Bengkulu, berdasarkan data tahun 2010 pasien jantung berjumlah 534 orang, sedangkan jumlah kunjungan baru yang didapat dari poli jantung pada tahun 2011 berjumlah 405 orang, sedangkan kunjungan baru tahun 2012 triwulan I sampai triwulan III sebanyak 623 pasien, sedangkan kunjungan baru tahun 2013 berjumlah 9570 orang dan untuk pasien jantung koroner rata-rata setiap bulannya pasien yang berkunjung sebanyak 120 orang.

Penelitian ini bertujuan untuk mengetahui hubungan konsumsi serat, kalium dan hubungannya dengan kadar low density lipoprotein pada pasien penyakit jantung koroner di RSUD Dr.M.Yunus Bengkulu.

\section{BAHAN DAN CARA KERJA}

Jenis penelitian ini adalah obsevasional analitik dengan rancangan cross sectional. Penelitian dilaksanakan di Rawat Jalan Poli Penyakit Jantung RSUD Dr.M Yunus Bengkulu, populasi penelitian adalah semua pasien rawat jalan di Poli Jantung dengan kriteria inklusi Usia dewasa (> 20 tahun), memiliki data laboratorium (kadar LDL) terbaru selama yaitu 3 bulan terakhir. Bertempat tinggal di Kota Bengkulu.

Besar sampel yang diteliti sebanyak 81 orang yang dihitung berdasarkan formula untuk satu populasi dengan tingkat kepercayaan $95 \%$. Pemilihan sampel dilakukan tanpa probabilitas secara purposive sampling dengan menentukan subjek dalam populasi yang sesuai dengan kreteria inklusi. Penelitian dilaksanakan bulan Januari sampai Maret 2015.

Variabel penelitian ini terdiri dari variabel terikat kadar LDL dan variabel bebas yaitu konsumsi serat dan kalium. Jenis data yang dikumpulkan meliputi data identitas dengan wawancara mengunakan formulir identitas subjek, Data laboratorium kadar LDL. Metode Food Frequency Questionaire (FFQ) semi kuantitatif, digunakan untuk mengetahui kebiasaan makan subjek selama tiga bulan terakhir dengan pengisian kolom sesuai dengan frekuensi 
(keseringan) konsumsi makanan yang termuat dalam daftar formulir konsumsi serat dan kalium. Data asupan yang telah terkumpul dihitung jumlah asupan serat dan kalium dengan menggunakan program Nutrisurvey dan menggunakan analisis statistic univariat dan bivariat dengan analisis pearson korelasi.

\section{HASIL}

Tabel 1. Gambaran Konsumsi serat, Konsumsi kalium dan Kadar Kolesterol LDL

\begin{tabular}{lllll}
\hline Variabel & Mean & SD & Min & Maks \\
\hline $\begin{array}{l}\text { Konsumsi } \\
\text { serat }\end{array}$ & 12.99 & 6.11 & 3.10 & 31.70 \\
$\begin{array}{l}\text { Konsumsi } \\
\begin{array}{l}\text { Kalium } \\
\text { LDL }\end{array}\end{array}$ & 1549.77 & 571.96 & 491.85 & 2856.50 \\
\hline
\end{tabular}

Berdasarkan tabel 1 diketahui bahwa rata rata kadar LDL $186.78 \mathrm{mg} / \mathrm{dL}$ diatas nilai normal yaitu $\geq 160 \mathrm{mg} / \mathrm{dL}$. Konsumsi serat masih rendah yaitu rata-rata $12.99 \mathrm{mg}$ dan konsumsi kalium rata-rata $1549.77 \mathrm{mg}$.

Tabel 2 menunjukkan bahwa hubungan antara konsumsi serat, konsumsi kalium dengan kadar kolesterol LDL dimana hasil koefisien kolerasi masing-masing -0.363 dan -0.449, hasil tesebut menunjukkan terjadi hubungan yang negatif, sehingga dapat diramalkan bahwa bila konsumsi serat dan kalium ditingkatkan, maka akan diikuti dengan terjadinya penurunan kadar kolesterol LDL.

Tabel 2. Hubungan konsumsi serat, konsumsi kalium dengan kadar kolesterol LDL

\begin{tabular}{|c|c|c|c|}
\hline \multicolumn{2}{|c|}{ Variabel } & \multirow{2}{*}{ Nilai P } & \multirow{2}{*}{ Nilai $r$} \\
\hline Dependen & Independen & & \\
\hline \multirow{2}{*}{$\begin{array}{c}\text { Kadar } \\
\text { Kolesterol } \\
\text { LDL }\end{array}$} & Konsumsi & 0.000 & -0.363 \\
\hline & $\begin{array}{c}\text { Konsumsi } \\
\text { Kalium }\end{array}$ & 0.000 & $-0,449$ \\
\hline
\end{tabular}

\section{PEMBAHASAN}

\section{Hubungan Konsumsi Serat Dengan Kadar Kolesterol LDL}

Hasil uji statistik didapatkan hasil ada hubungan yang bermakna menggunakan Korelasi Pearson. Konsumsi serat dengan kadar kolesterol LDL menunjukan hubungan yang sedang artinya semakin rendah kon- sumsi serat maka semakin tinggi nilai kadar kolesterol LDL. Rata-rata konsumsi serat pada pasien Jantung Koroner di RSUD M. Yunus Bengkulu adalah 12,99 gram dengan asupan serat terendah yaitu 3,10 gram dan yang tertinggi yaitu 31,70 gram. Bila dibandingkan dengan anjuran WHO konsumsi serat makanan pada penderita jantung koroner masih dibawah anjuran yaitu 25 gram/hari. Konsumsi bahan makanan serat yang dikonsumsi oleh pasien PJK antara lain daun kacang panjang, daun lumay, papaya muda, terong dan daun singkong. Sedangkan rata-rata kadar kolesterol LDL pada pasien Jantung Koroner di RSUD M. Yunus Bengkulu adalah 186,78 mg/dL menunjukkan kadar LDL tinggi (batasan LDL $150 \mathrm{mg} / \mathrm{dl}$ ).

Asupan serat yang kurang dapat mengakibatkan asam empedu kurang dalam mengemulsikan lemak menjadi feses. Sehingga kadar kolesterol LDL dalam darah dapat meningkat. Serat ditemukan dalam buah-buahan, sayur-sayuran serta beberapa jenis kacang-kacangan. Serat tersebut terlarut dan membentuk gel dalam air. Bentukkan gel ini dalam saluran pencernaan menyebabkan kecepatan melambat dalam mendorong komponen makanan ke usus, dengan demikian absorbsi kolesterol dan lemak lainnya melambat, sehingga terjadi peningkatan produksi asam lemak rantai pendek dengan cara fermentasi (Achadi, 2007). Sejalan dengan penelitian Muzakar, 2010 di Palembang disimpulkan terdapat hubungan yang bermakna antara asupan serat yang rendah dengan status dislipidemia. (kolesterol, HDL, dan LDL) pada penderita PJK. Mengurangi makanan yang tinggi lemak dan diimbangi dengan konsumsi serat setiap hari akan mampu mengurangi kadar kolesterol LDL didalam tubuh. Kandungan jenis serat yang dikunsumsi, apakah termasuk serat larut atau tidak larut harus diketahui sehingga kontribusi serat untuk dapat mempengaruhi kadar kolesterol LDL.

Hasil penelitian ini dapat dilihat asupan serat yang tinggi masih membuat kadar kolesterol LDL tinggi dikarenakan proses metabolisme di dalam tubuh. Sehingga dapat disimpulkan, banyak faktor lain yang 
dapat mempengaruhi peningkatan kadar kolesterol LDL pada seseorang. LDL dilipolisis oleh hepatic trigliserida lipase (HTGL) yaitu enzim yang diproduksi dihati, kedua proses tersebut terjadi didinding endotel. Jadi dalam hal ini penyebab tingginya LDL dapat juga disebabkan oleh kelainan metabolisme yang disebabkan tidak adanya atau defisiensi enzim LPL, HTGL, dan Apo CII sebagai kofaktor.

\section{Hubungan Konsumsi Kalium Dengan Kadar Kolesterol LDL}

Konsumsi kalium dengan kadar kolesterol LDL menunjukan hubungan yang sedang artinya semakin tinggi konsumsi kalium maka semakin rendah nilai kadar kolesterol LDL. Hasil uji statistik didapatkan ada hubungan yang bermakna dengan Rata-rata konsumsi kalium pada pasien Jantung Koroner adalah 1549,77 mg dengan asupan kalium terendah yaitu 491,85 mg dan yang tertinggi yaitu $2856,50 \mathrm{mg}$. Bila dibandingkan dengan anjuran konsumsi kalium makanan pada penderita jantung koroner masih dibawah anjuran yaitu 1600-2800 $\mathrm{mg} / \mathrm{hr}$. Konsumsi bahan makanan kalium yang dikonsumsi oleh pasien PJK antara lain pisang, kacang tanah, jeruk dan kelapa. Rata-rata kadar kolesterol LDL pada pasien jantung koroner di RSUD M. Yunus Bengkulu adalah 186,78 mg/dl menunjukkan melampaui batas normal kadar LDL $150 \mathrm{mg} / \mathrm{dl}$.

Kalium merupakan salah satu mineral penting yang dapat membuang kolesterol jahat

\section{DAFTAR RUJUKAN}

Achadi, E. 2007. Gizi dan Kesehatan Masyarakat. Jakarta : PT. Raja Grafindo Persada.

Almatsier, R. 2009. Penuntun Diet Edisi Terbaru. Jakarta : Gramedia Pustaka.

Andriatoro. 2007. Buku ajar ilmu penyakit dalam jilid $i$. Edisi 2. Jakarta : FKUI.

Brasher, L.V. 2008. Aplikasi Klinis Patofisiologi Pemeriksaan dan Manajemen (Ed. 2). Jakarta : Buku Kedokteran.

Brunner, dkk. 2000. Keperawatan Medical Bedah. Jakarta : EGC.

Bustan, MN. 2007. Epidemiologi Penyakit Tidak Menular. Jakarta : Rineka Cipta.

Deddy Muchtadi, 2001. Sayuran Sebagai Sumber Serat Pangan untuk Mencegah Timbulnya
LDL yang menyumbat pembuluh darah sehingga darah dapat mengalir dengan lancar (Soeditama, 2008). Sehingga bila kekurangan kalium dapat mengakibatkan lemah, lesu, kehilangan nafsu makan, kelumpuhan, mengigau, serta jantung berdebar keras, detak dan menurunkan kemampuan untuk memompa darah (Almatsier, 2003).

Hasil penelitian ini diperoleh bahwa subjek/pasien untuk menilai asupan kalium yang tinggi,namun tidak diikuti penurunan kadar kolesterol LDL dikarenakan proses metabolisme di dalam tubuh. Sehingga dapat disimpulkan, banyak faktor lain yang dapat mempengaruhi peningkatan kadar kolesterol LDL pada seseorang. Pemilihan makanan yang tinggi kalium yang terdapat pada sayuran hijau dapat membuang kolesterol jahat dalam pembuluh darah, sehingga mengurangi risiko terkena penyakit jantung koroner.

\section{KESIMPULAN}

Hasil penelitian disimpulkan bahwa ada hubungan yang bermakna antara konsumsi serat dan konsumsi kalium dengan kadar kolesterol LDL pada pesien penyakit jantung koroner.

Perlu adanya edukasi untuk meningkatkan kesadaran dan sosialisasi pedoman gizi seimbang pada masyarakat, mengingat pola makanan yang cenderung kurang serat dan kalium. Khususnya penderita agar mereka. Mengkonsumsi sumber kalium dan serat sesuai Aangka Kecukupan Gizi (AKG).

Penyakit Degeneratif. Jurnal Teknol. dan Industri Pangan, Vol. XII, No. 1 Th 2005.

Delmi. 2005. Pola asupan lemak, serat dan antioksidan serta hubungannya dengan profil lipid pada laki-laki etnik Minangkabau. Fakultas kedokteran Universitas Andalas, Padang.

Depkes RI. (2013). Riset Kesehatan Dasar (RISKESDAS). Laporan Nasional Badan Penelitian dan Pengembangan Kesehatan Departemen Kesehatan Republik Indonesia.

Dwi, Silfa. 2013. Hubungan asupan makanan dan Rasio lingkar pinggang terhadap kadar kolesterol total pada pasien jantung koroner Rumah Sakit M.Yunus Kota Bengkulu. Universitas Muhammadyah. Bengkulu. 
Ervira, Desty. 2013. Keajaiban Dari Buah. Jakarta : PT AgroMedia Pustaka.

Escudero, N.L; Zirulnik F; Gomez N.N; Mucciarelli S.I; Gimenez M.S. 2006. Influence of a Protein Concentrate from Amaranthus cruentus Seeds on Lipid Metabolism. Exp Biol Med 231:50-9 PubMed, Web of Science.

Fatimah, dkk. 2013. Hubungan obesitas, asupan natrium dan kalium dengan tekanan darah pada mahasiswa Universitas Hasanuddin angkatan 2013. Universitas Hasanuddin, Sulawesi Selatan.

Gray, dkk. 2005. Lecture Note Kardiologi. Edisi ke Empat. Jakarta : Erlangga.

Hartono, Andry. 2006. Terapi Gizi dan Diet Rumah sakit. Jakarta : EGC.

Helmizar, dkk. 2010. Jurnal : Hubungan tingkat konsumsi antioksidan dengan profil lipid darah orang dewasa etnis minangkabau di kota Padang. Fakultas kedokteran, Universitas Andalas, Padang.

Hutter CM, Melissa AA, Steve EH. 2004. Familial hypercholesterolemia, peripheral arterial disease, and stroke: a huge minireview. American Journal of Epidemiology 160: 430435.

Kabo, peter. 2008. Pengobatan Jantung Koroner. Jakarta : PT Gramedia Pustaka Utama.

Kamso S. 2007. Dislipidemia dan obesitas sentral pada lanjut usia di Kota Padang. J Kes Mas Nas. 2:73-77.

Khomsan, A. 2004. Peranan Pangan dan Gizi Untuk Kualitas Hidup. Jakarta : PT. Grasindo.

Kowalski, Robert E. 2010. Terapi Hipertensi. Bandung : PT Mizan Pustaka.

Krisnatuti D, Yenrina R. 2005. Perencanaan Меnu Bagi Penderita Jantung Koroner. Jakarta : Trubus Agriwidya.

Lawrence, Stephen, \& Maxine. 2002. Diagnosis dan terapi kedokteran ilmu penyakit dalam. Jakarta : Salemba Medika.

Majid A. 2007. Penyakit Jantung Koroner : Patofisiologi, Pencegahan Dan Pengobatan Terkini. Pidato Pengukuhan Jabatan Guru Besar Tetap Dalam Bidang Ilmu Fisiologi Pada Fakultas Kedokteran. Universitas Sumatera Utara; Medan, 4 Agustus 2007. Medan: Universitas Sumatera Utara.

Marks, Dawn. 2000. Biokimia Kedokteran Dasar. Jakarta : EGC.

Mitchell, Kumar, Abbas \& Fausto. 2006. Dasar Patologis Penyakit. Jakarta: EGC.

Muzakar,yeni prawiningdyah, Hermi astitu . Asupan vitamin B3 (niasin ) C,E dan serat terhadap dislipidemia pada Penyakit Jantung Koroner di RS.DR Mohammad hoaesin Palembang. JurnaL Gizi klinik Indoensia volume 6 no 3 maret 2010 .
Nilawati, Krisnatuti, Mahendra dan Gin Djing. 2008. Care Yourself, Kolesterol. Jakarta. Penebar Plus.

Norhashimah. 2010. Gambaran Pengetahuan Dan Sikap Masyarakat Tentang Penyakit Jantung Koroner (PJK) Di Kelurahan Tanjung Rejo [skripsi]. Medan : Fakultas kedokteran, Universitas Sumatera Utara.

Profil RSUD M Yunus Bengkulu tahun 2014. Data terolah, Bengkulu

Rahajeng, Tuminah \& Sulistyowati T. 2009. Prevalensi Hipertensi dan Determinannya di Indonesia. Maj Kedokt Indon, Volume : 59, Nomor: 12, Halaman 580-587.

Ronny, dkk. 2009. Fisiologi Kardiovaskular Berbasis Masalah Keperawatan. Jakarta: EGC

Sadewantoro. Penyakit Jantung Koroner dan Faktor Risikonya. Dalam Sadewantoro, Bagus, T., Rudianto, Deni. (eds). Kumpulan Makalah Seminar Sehari: Penyakit Jantung Koroner dan Hipertensi, Penatalaksanaan Keperawatan pada Penderita PJK dan Hipertensi. Rumkital Dr. Ramelan, FK UHF dan Akper Hang Tuah, Surabaya, 2004:1-19.

Santoso, Novianto Budi. 2002. Jurnal : KADAR KALIUM SERUM DAN ASUPAN KALIUM YANG RENDAH SEBAGAI FAKTOR RISIKO STROKE ISKEMIK TROMBOTIK. Surabaya. Universitas Airlangga.

Soeharto, Iman. 2004. Serangan Jantung dan Stroke Hubungannya dengan Lemak \& Kolesterol. Jakarta. PT. Gramedia Pustaka Utama.

Sugiani,PPS,Hadi H, Pramantara IDP, Asupan Gizi sebagai factor resiko penyakit Infark Miokad Akut di RS Sanglah Denpasar.Jurnal Gizi Klinik Indonesia 2004;1(2):67-75

Sulastri, delmi. 2005. Jurnal : Pola Asupan Lemak, Serat dan Antioksidan, serta Hubungannya dengan Profil Lipid pada Laki-laki Etnik Minangkabau. Universitas Andalas. Padang.

Supriyono, Mamat. 2008. Faktor-Faktor Risiko yang Berpengaruh Terhadap Kejadian Penyakit Jantung Koroner pada Kelompok Usia $\leq 45$ Tahun. Universitas diponegoro semarang.

Tamsuri, Anas. 2009. Klien gangguan keseimbangan cairan dan elektrolit. Jakarta : EGC

Tapan, Erik. 2005. Penyakit Degeneratif. Jakarta : Gramedia Pustaka Utama.

Wijayakusuma. 2005. Buku Ajar Fisiologi Kedokteran. Jakarta : EGC.

Winarsi, Hery. 2007. Antioksidan Alami dan Radikal Bebas. Yogyakarta : KANISIUS.

Wiryowidagdo. 2005. Buku Ajar Ilmu Penyakit Dalam Jilid 3. Edisi kedua. Jakarta : FKUI.

Wiyono, dkk. 2008. Hubungan Konsumsi Sayur dan Buah dengan Kadar Kolesterol Peserta Senam Jantung Sehat Yayasan Wijaya Kusuma Kelurahan Mekarsari Kecamatan Cimanggis. Universitas Esa Unggul. Jakarta. 